\title{
Glutamate Receptors on Myelinated Spinal Cord Axons: II. AMPA and GluR5 Receptors
}

\author{
Mohamed Ouardouz, PhD, ${ }^{1}$ Elaine Coderre, ${ }^{1}$ Gerald W. Zamponi, PhD, ${ }^{2}$ Shameed Hameed, PhD, ${ }^{2}$
} Xinghua Yin, $\mathrm{MD},{ }^{3}$ Bruce D. Trapp, $\mathrm{PhD},{ }^{3}$ and Peter K. Stys, $\mathrm{MD}^{4}$

\begin{abstract}
Objective: Glutamate receptors, which play a major role in the physiology and pathology of central nervous system gray matter, are also involved in the pathophysiology of white matter. However, the cellular and molecular mechanisms responsible for excitotoxic damage to white matter elements are not fully understood. We explored the roles of AMPA and GluR5 kainate receptors in axonal $\mathrm{Ca}^{2+}$ deregulation.

Methods: Dorsal column axons were loaded with a $\mathrm{Ca}^{2+}$ indicator and imaged in vitro using confocal microscopy.

Results: Both AMPA and a GluR5 kainate receptor agonist increased intraaxonal $\mathrm{Ca}^{2+}$ in myelinated rat dorsal column fibers. These responses were inhibited by selective antagonists of these receptors. The GluR5-mediated $\mathrm{Ca}^{2+}$ increase was mediated by both canonical (ie, ionotropic) and noncanonical (metabotropic) signaling, dependent on a pertussis toxin-sensitive G protein/ phospholipase C-dependent pathway, promoting $\mathrm{Ca}^{2+}$ release from inositol triphosphate-dependent stores. In addition, the GluR5 response was reduced by intraaxonal NO scavengers. In contrast, GluR4 AMPA receptors operated via $\mathrm{Ca}^{2+}$-induced $\mathrm{Ca}^{2+}$ release, dependent on ryanodine receptors, and unaffected by NO scavengers. Neither pathway depended on L-type $\mathrm{Ca}^{2+}$ channels, in contrast with GluR6 kainate receptor action. ${ }^{1}$ Immunohistochemistry confirmed the presence of GluR4 and GluR5 clustered at the surface of myelinated axons; GluR5 coimmunoprecipitated with nNOS and often colocalized with neuronal nitric oxide synthase clusters on the internodal axon.

Interpretation: Central myelinated axons express functional AMPA and GluR5 kainate receptors, and can directly respond to glutamate receptor agonists. These glutamate receptor-dependent signaling pathways promote an increase in intraaxonal $\mathrm{Ca}^{2+}$ levels potentially contributing to axonal degeneration.
\end{abstract}

Ann Neurol 2009;65:160-166

The precise mechanisms of glutamate-mediated toxicity in white matter are not completely established. This transmitter likely causes damage to glia given that both astrocytes and oligodendrocytes express a variety of glutamate receptors, ${ }^{2-8}$ with oligodendrocytes being particularly vulnerable to excitotoxic cell death. ${ }^{9-12}$ Whether glutamatergic signaling is directly involved in irreversible axonal injury in disorders such as stroke, multiple sclerosis, and neurotrauma is not known, though a role for glutamate-dependent excitotoxicity is suspected given the protective effects of $\alpha$-amino-3-hydroxy-5-methyl-4isoxazolepropionic acid (AMPA)/kainate antagonists in models of spinal cord injury, stroke, and experimental autoimmune encephalomyelitis. ${ }^{2,4,13-18}$ The beneficial effect of glutamate antagonism was hypothesized to be caused by sparing of glia and myelin, but the observed axonal protection remains unexplained. To date, no con- clusive data exist showing expression of functional glutamate receptors on central myelinated axons. Here, we show that myelinated dorsal column axons express glutamate receptor subunit 4 (GluR4) AMPA receptors and GluR5 kainate receptors; the GluR5 effect is mediated in large part via a noncanonical mechanism through activation of $\mathrm{G}$ protein, phospholipase $\mathrm{C}$, and release of $\mathrm{Ca}^{2+}$ from intracellular stores by activation of inositol triphosphate (IP3) receptors. GluR4 AMPA receptors, on the other hand, appear to participate in $\mathrm{Ca}^{2+}$ induced $\mathrm{Ca}^{2+}$ release (CICR) through ryanodinedependent $\mathrm{Ca}^{2+}$ stores.

\section{Materials and Methods \\ $\mathrm{Ca}^{2+}$ Imaging}

Experiments were performed on spinal cord dorsal columns in vitro from adult Long-Evans male rats. Thoracic spinal
From the ${ }^{1}$ Division of Neuroscience, Ottawa Health Research Institute, University of Ottawa, Ottawa, Ontario; ${ }^{2}$ Department of Physiology and Biophysics, Hotchkiss Brain Institute, University of Calgary, Calgary, Alberta, Canada; ${ }^{3}$ Department of Neurosciences, Cleveland Clinic Foundation, Cleveland, $\mathrm{OH}$; and ${ }^{4}$ Department of Clinical Neurosciences, Hotchkiss Brain Institute, University of Calgary, Calgary, Alberta, Canada.

Address correspondence to Dr Stys, Department of Clinical Neurosciences, HRIC 1AA22, 3330 Hospital Drive NW, AB, Canada, T2N 4N1. E-mail: pstys@ucalgary.ca
Potential conflict of interest: Nothing to report.

Received Aug 5, 2008, and in revised form Aug 25. Accepted for publication Aug 29, 2008.

Published online in Wiley InterScience (www.interscience.wiley.com). DOI: 10.1002 /ana.21539 
cord was removed and placed in cold oxygenated zero- $\mathrm{Ca}^{2+}$ solution containing (in $\mathrm{mM}$ ) $\mathrm{NaCl} 126, \mathrm{KCl} 3, \mathrm{MgSO}_{4} 2$, $\mathrm{NaHCO}_{3} 26, \mathrm{NaH}_{2} \mathrm{PO}_{4} 1.25, \mathrm{MgCl}_{2}$ 2, dextrose 10, and EGTA 0.5 , oxygenated with $95 \% \mathrm{O}_{2} / 5 \% \mathrm{CO}_{2}$. Freshly excised dorsal columns were loaded for 2 hours with $\mathrm{Ca}^{2+}$ insensitive reference dye $(250 \mu \mathrm{M}$ red dextran-conjugated $\mathrm{Al}$ exa 594) to allow identification of axon profiles, and the dextran-conjugated $\mathrm{Ca}^{2+}$ indicator Oregon Green BAPTA-1 $(250 \mu \mathrm{M})$ (both from Molecular Probes, Eugene, OR) using a suction electrode applied to the cut end. The final dye concentration in the axons was estimated at approximately $2 \mu \mathrm{M}$. Tissue was transferred to a custom-built chamber on a Nikon (Toronto, Ontario) C1 confocal microscope and imaged every 60 seconds at $37^{\circ} \mathrm{C}$ with a $60 \times 1.0 \mathrm{NA}$ water immersion lens warmed to $37^{\circ} \mathrm{C}$. Green signal was ratioed against the $\mathrm{Ca}^{2+}$-insensitive red channel; then percentage change during exposure to various agents compared with control was calculated. Pertussis toxin (PTX) was first activated by adding adenosine triphosphate $(1 \mathrm{mM})$ and glutathione $(2 \mathrm{mM})$, and incubated at $37^{\circ} \mathrm{C}$ overnight. Final PTX concentration in the loading pipette was $5 \mu \mathrm{M}$.

\section{Immunohistochemistry}

For light microscopy, deeply anesthetized rats were perfused with saline, then $4 \%$ paraformaldehyde in $0.1 \mathrm{M}$ phosphate buffer. Dorsal columns were excised, postfixed, and immersed in 20\% sucrose overnight. Forty-micrometer sections were cut with a freezing microtome and washed with Tris buffer containing 1\% Triton X-100 (Sigma Labs, St. Louis, $\mathrm{MO})$. After 1 hour block with 10\% normal goat serum in Triton X-100, primary antibodies against GluR5 (1:50; Chemicon International, Temecula, CA), GluR4 (1:50; Chemicon), neuronal nitric oxide synthase (nNOS; 1:100; Abcam, Cambridge, MA), and neurofilament 160 (NF160; 1:1,000; Sigma) were applied for 24 hours at $4^{\circ} \mathrm{C}$. Secondary antibodies (Texas red anti-rabbit or anti-mouse; Cedarlane, Burlington, NC) were applied at a 1:100 dilution, and Alexa 488 anti-goat and anti-rabbit (Molecular Probes) at 1:500 for 1 hour at room temperature. Neurofilament 160 directly conjugated to Alexa 660 was used at 1:100 dilution. Slides were imaged on a Nikon C1 confocal microscope with a $60 \times 1.4$ NA oil immersion objective.

Immunohistochemistry, immunoelectron microscopy, and immunochemistry were performed using standard techniques as described previously. ${ }^{1,19}$

\section{Statistics}

Means are shown with standard deviations. Statistical differences were computed using analysis of variance with Tukey's test for multiple comparisons using Igor (Wavemetrics, Lake Oswego, OR) unless otherwise stated. $\mathrm{N}$ values are numbers of individual axons unless otherwise noted.

\section{Results}

We measured relative $\left[\mathrm{Ca}^{2+}\right]$ changes in live adult rat spinal cord dorsal column myelinated axons using Oregon Green-488 BAPTA-1 fluorescence (Fig 1). GluR5-containing kainate receptors (hereafter referred to as GluR5s') were activated by the selective agonist $(R S)$-2-amino-3-(3-hydroxy-5-tert-butylisoxazol-4-yl)
A

ATPA

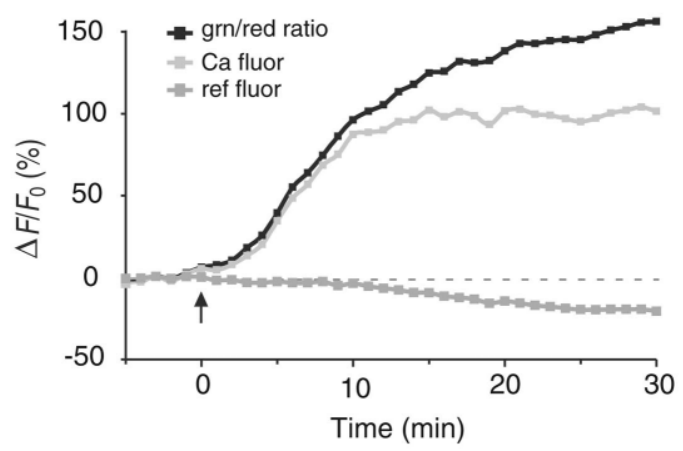

B

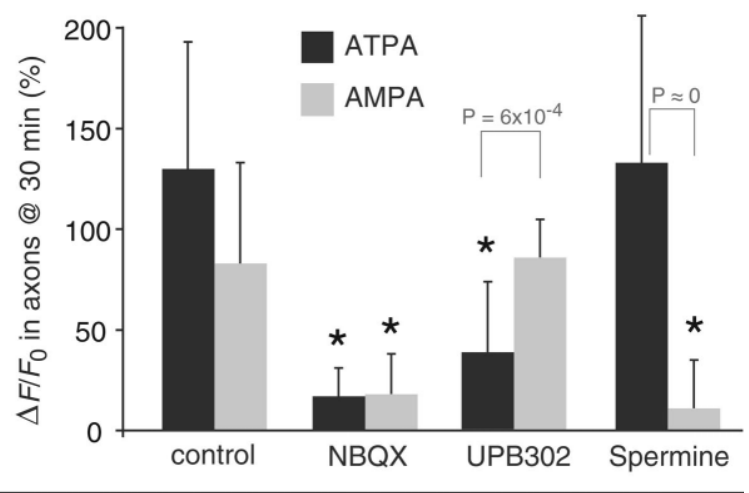

Fig 1. Change in $\left[\mathrm{Ca}^{2+}\right]$ in dorsal column axons in response to glutamate receptor 5 (GluR5) or $\alpha$-amino-3-hydroxy-5-methyl4-isoxazolepropionic acid (AMPA) receptor activation. (A) Representative time course of axonal $\mathrm{Ca}^{2+}$ increase in response to bath application of the GluR5 kainate receptor agonist (RS)-2amino-3-(3-hydroxy-5-tert-butylisoxazol-4-yl)propanoic acid (ATPA). The "green/red ratio" plot (black line) is the raw $\mathrm{Ca}^{2+}$-dependent fluorescence ("Ca fluor"; light gray line) corrected for the modest rundown estimated by signal from the $\mathrm{Ca}^{2+}$-independent Texas Red dextran dye ("ref fluor"; dark gray line). (B) Bar graph showing percentage change ( \pm standard deviation) of axonal $\mathrm{Ca}^{2+}$-dependent fluorescence after 30 minutes of agonist exposure. Activating GluR5 receptors with ATPA, or AMPA receptors using AMPA, induced a robust axonal $\mathrm{Ca}^{2+}$ increase that displayed the expected selectivity in response to antagonists. ${ }^{*} \mathrm{p}=10^{-5}$ compared with respective agonist controls.

propanoic acid (ATPA $10 \mu \mathrm{M}),{ }^{20}$ whereas the relatively selective agonist AMPA $(100 \mu \mathrm{M})$ was used to activate AMPA receptors. Both agents induced an increase in axoplasmic $\mathrm{Ca}^{2+}$-dependent fluorescence $\left(\mathrm{F}_{\text {Ca.ax }}\right)$ (mean increase after 30 minutes: $130 \pm 63 \%, \mathrm{n}=53$ axons for ATPA; $83 \pm 50 \%, \mathrm{n}=56$ for AMPA), which was largely blocked by the combined AMPA/ kainate receptor antagonist 2,3-dihydroxy-6-nitro-7sulfamoyl-benzoquinoxaline-2,3-dione (NBQX $50 \mu \mathrm{M}$, $\mathrm{F}_{\text {Ca.ax }}$ increase at 30 minutes: $17 \pm 14 \%, \mathrm{n}=32$ with ATPA; $18 \pm 20 \%, \mathrm{n}=45$ with AMPA; $p=10^{-5}$ vs 
agonist alone, both groups). In contrast, the GluR5 antagonist (S)-1-(2-amino-2-carboxyethyl)-3-(2-carboxybenzyl)pyrimidine-2,4-dione (UPB302 $20 \mu \mathrm{M})^{21}$ selectively reduced the ATPA-induced response $\left(\mathrm{F}_{\mathrm{Ca} . \mathrm{ax}}\right.$ increase $38 \pm 35 \%, \mathrm{n}=48, p=10^{-5}$ vs ATPA alone) but had no effect on the AMPA-induced $\mathrm{Ca}^{2+}$ increase ( $85 \pm 19 \%, \mathrm{n}=27, p \approx 1$ vs AMPA alone). Comparing the $\mathrm{Ca}^{2+}$ responses elicited by AMPA versus ATPA in the presence of UPB302 also yielded a highly significant difference $\left(p=6 \times 10^{-4}\right)$, further supporting the relatively selective block of GluR5 over AMPA receptors by this antagonist. Conversely, the AMPA receptor antagonist 1-naphthyl acetyl spermine did not reduce the ATPA-induced $\mathrm{F}_{\text {Ca.ax }}$ increase $(133 \pm 73 \%$; $\mathrm{n}=44 ; p=1$ ) but strongly reduced the response elicited by AMPA $\left(11 \pm 24 \% ; \mathrm{n}=32 ; p=10^{-5}\right)$ (see Fig 1). Taken together, these findings strongly suggest that ATPA preferentially activated GluR5s,' whereas AMPA acted as a selective agonist of AMPA receptors in our tissue.

To further characterize the source of $\mathrm{Ca}^{2+}$ mobilized by activation of GluR5 or AMPA receptors, we performed experiments in $\mathrm{Ca}^{2+}$-free perfusate, with the addition of $0.5 \mathrm{mM}$ EGTA (Fig 2). Under these conditions, the ATPA-induced $\mathrm{Ca}^{2+}$ increase was significantly reduced but not abolished ( $\mathrm{F}_{\text {Ca.ax }}$ increase: $43 \pm$ $31 \%, \mathrm{n}=36, p=10^{-5}$ vs ATPA in normal $\mathrm{Ca}^{2+}$ ), suggesting that part of the GluR5-dependent effect was mediated by $\mathrm{Ca}^{2+}$ release from intracellular stores independent of extracellular $\mathrm{Ca}^{2+}$. In contrast, the AMPA response was virtually abolished in zero- $\mathrm{Ca}^{2+}$ perfusate $\left(\mathrm{F}_{\text {Ca.ax }}\right.$ increase: $6 \pm 23 \%, \mathrm{n}=27, p=$ $10^{-5}$ vs AMPA in normal $\mathrm{Ca}^{2+}$ ). We previously showed that activation of axonal voltage-gated $\mathrm{Ca}^{2+}$ channels leads to $\mathrm{Ca}^{2+}$ release from axonal $\mathrm{Ca}^{2+}$ stores and is an important mechanism contributing to $\mathrm{Ca}^{2+}$ overload in damaged central axons. ${ }^{22}$ We therefore examined the effect of nimodipine $(10 \mu \mathrm{M})$ to investigate any involvement of L-type $\mathrm{Ca}^{2+}$ channels. This blocker did not reduce the ATPA- or the AMPAinduced $\mathrm{F}_{\mathrm{Ca} \text {.ax }}$ increase (see Fig 2), indicating that these receptors induced axonal $\mathrm{Ca}^{2+}$ increases independently of L-type $\mathrm{Ca}^{2+}$ channel activation.

Kainate receptor signaling may occur either ionotropically or metabotropically via receptor coupling to $\mathrm{G}$ proteins. ${ }^{23,24}$ For instance, in cultured dorsal root ganglion cells that express GluR5 subunits, activation of GluR5-containing kainate receptors induces a metabotropic action with release of $\mathrm{Ca}^{2+}$ from intracellular stores through activation of $\mathrm{G}$ proteins and phospholipase C. ${ }^{24}$ We loaded spinal axons with PTX (see Materials and Methods) designed to inhibit G-protein signaling. Under these conditions, the axonal $\mathrm{Ca}^{2+}$ increase in response to ATPA application was greatly reduced $\left(\mathrm{F}_{\text {Ca.ax }}\right.$ increase: $17 \pm 28 \%, \mathrm{n}=$ $38, p=10^{-5}$ vs no PTX). Moreover, either inhibition

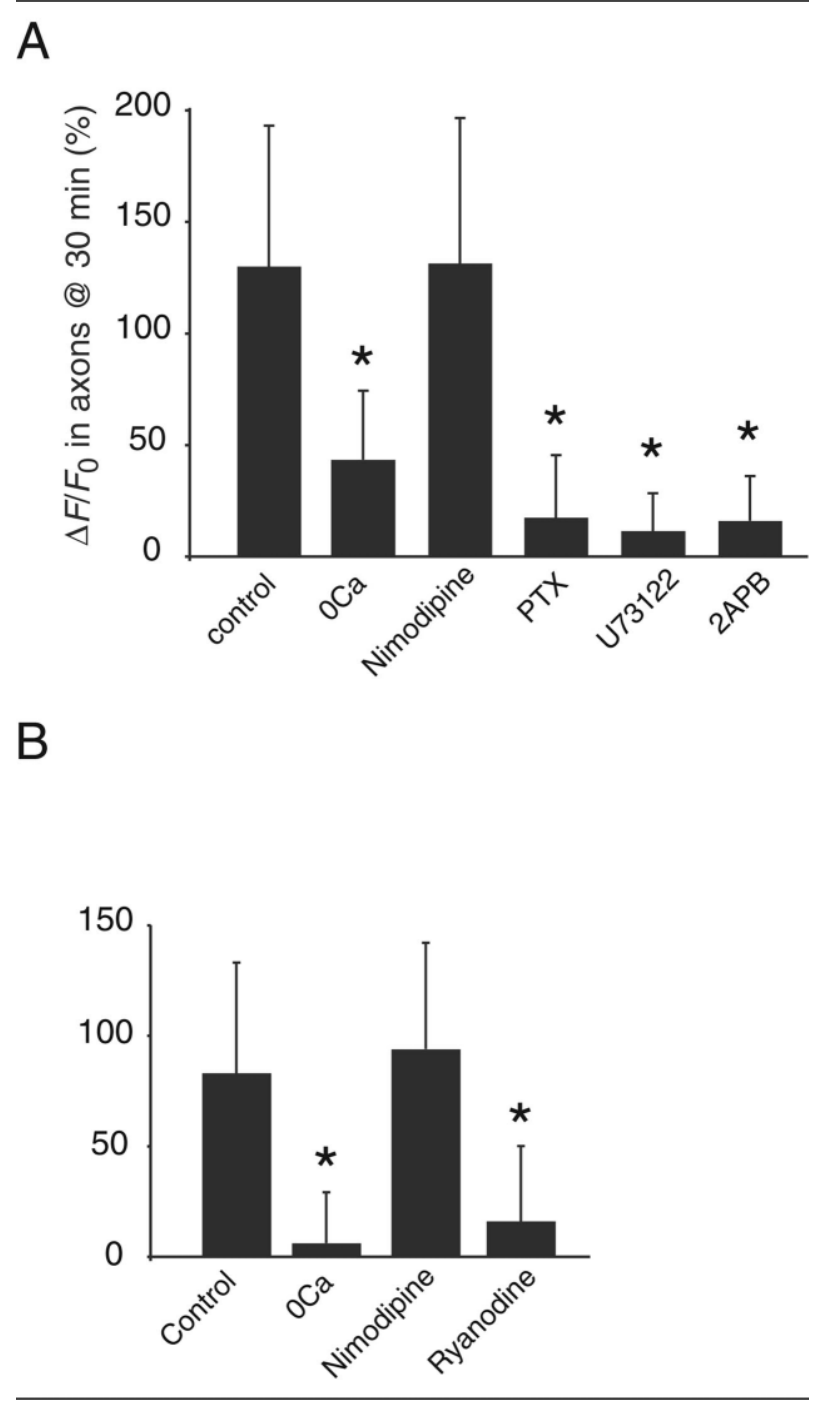

Fig 2. Glutamate receptor 5 (GluR5) and $\alpha$-amino-3hydroxy-5-methyl-4-isoxazolepropionic acid (AMPA) receptors promote $\mathrm{Ca}^{2+}$ release from internal stores. (A) $\mathrm{Ca}^{2+}$-free perfusate significantly reduced but did not eliminate (RS)-2amino-3-(3-hydroxy-5-tert-butylisoxazol-4-yl)propanoic acid (ATPA)-induced $\mathrm{Ca}^{2+}$ increase, pointing to a role of intracellular stores. Nimodipine, an L-type, voltage-gated, $\mathrm{Ca}^{2+}$ channel blocker, was ineffective in reducing ATPA responses. Loading the axons with pertussis toxin (PTX) to inhibit G-protein signaling, inhibition of phospholipase $C$ (U73122), or blocking inositol triphosphate (IP3) receptors (2-aminoethoxydiphenyl borate [2-APB]) each greatly reduced the ATPA-induced $\mathrm{Ca}^{2+}$ increase, indicating a G-protein-coupled mechanism leading to release from IP3-dependent $\mathrm{Ca}^{2+}$ stores. (B) In contrast, the AMPA-induced $\mathrm{Ca}^{2+}$ response was abolished by removal of external $\mathrm{Ca}^{2+}$, whereas nimodipine was ineffective. Blocking ryanodine receptors directly strongly reduced $\mathrm{Ca}^{2+}$ responses induced by AMPA even in the presence of $2 m M$ bath $\mathrm{Ca}^{2+}$, suggesting that most of the agonist-induced $\mathrm{Ca}^{2+}$ increase is due to release from ryanodine-sensitive $\mathrm{Ca}^{2+}$ stores, rather than from influx across the axolemma. ${ }^{*} \mathrm{p} \leq 10^{-5}$ compared with respective agonist controls. 
of phospholipase C by U73122 $(10 \mu \mathrm{M})$ or antagonism of IP3 receptors by 2-aminoethoxydiphenyl borate (2APB $100 \mu \mathrm{M})$ reduced ATPA-induced $\mathrm{Ca}^{2+}$ increase to a degree comparable to PTX $\left(\mathrm{F}_{\mathrm{Ca} . \mathrm{ax}}\right.$ increase in U73122: $11 \pm 17 \%, \mathrm{n}=33$; 2 -APB: $16 \pm 20 \%, \mathrm{n}=$ 27; $p=10^{-7}$ vs no drug). Taken together, these data suggest that although axonal ATPA-induced GluR5 responses exhibit some dependence on extracellular $\mathrm{Ca}^{2+}$, the bulk of the resulting axonal $\mathrm{Ca}^{2+}$ increase in response to activation of these receptors was mediated mainly by noncanonical signaling through $G$ proteins, activation of PLC, and release of $\mathrm{Ca}^{2+}$ from intraaxonal IP3-dependent $\mathrm{Ca}^{2+}$ stores.

In contrast, the near-complete abolition of axonal $\mathrm{Ca}^{2+}$ increase in response to AMPA in zero-external $\mathrm{Ca}^{2+}$ perfusate suggests that AMPA receptors permeate $\mathrm{Ca}^{2+}$ directly into myelinated spinal axons; however, this extracellular $\mathrm{Ca}^{2+}$ dependence does not exclude an intracellular $\mathrm{Ca}^{2+}$ source, through a $\mathrm{Ca}^{2+}$-induced $\mathrm{Ca}^{2+}$-release mechanism, for instance. Indeed, ryanodine $(50 \mu \mathrm{M})$, a selective antagonist of ryanodine receptors present on endoplasmic reticulum, significantly reduced AMPA receptor-mediated axonal $\mathrm{Ca}^{2+}$ increase (16 $\pm 34 \%, \mathrm{n}=26, p=10^{-7}$ vs no ryanodine). Thus, the strong dependence of AMPA responses on external $\mathrm{Ca}^{2+}$, coupled with the significant inhibitory effects of ryanodine, indicates that although AMPA receptors do permeate $\mathrm{Ca}^{2+}$ directly, the majority of the resulting axonal $\mathrm{Ca}^{2+}$ signal is due to CICR from ryanodine-dependent intracellular stores, similar to CICR classically described in cardiac muscle cells. ${ }^{25}$ However, unlike cardiac myocytes, the initial $\mathrm{Ca}^{2+}$ "trigger" appears to be delivered by $\mathrm{Ca}^{2+}$-permeable AMPA receptors; this is consistent with the strong inhibitory effect of 1-naphthyl acetyl spermine, a selective inhibitor of GluR2-lacking, $\mathrm{Ca}^{2+}$-permeable AMPA receptors, on the AMPA-induced $\mathrm{Ca}^{2+}$ increase (see Fig 1). Together with our previous data from spinal axons showing that depolarization promotes $\mathrm{Ca}^{2+}$ release from ryanodine-sensitive $\mathrm{Ca}^{2+}$ stores, ${ }^{22}$ these results indicate that axons exhibit both a depolarization-induced (skeletal muscle type, dependent on ryanodine receptor 1 [RyR1]) and a $\mathrm{Ca}^{2+}$ induced (cardiac muscle type, RyR2) $\mathrm{Ca}^{2+}$ release. Indeed, both RyR1 and RyR2 are expressed in these axons ${ }^{22}$; whether AMPA receptor-mediated $\mathrm{Ca}^{2+}$ influx indicated by this study acts selectively on axonal RyR2 is currently unknown, however. $\mathrm{Ca}^{2+}$ release via IP3 receptors is also known to be potentiated by increased cytosolic- $\mathrm{Ca}^{2+}$ in a biphasic manner. ${ }^{26}$ The significant, though incomplete, reduction of $\mathrm{Ca}^{2+}$ increase by zero- $\mathrm{Ca}^{2+}$ perfusion in response to ATPA is consistent with a dual action of GluR5s', reflecting a small component of $\mathrm{Ca}^{2+}$ entry (see the next section) coupled with a strong metabotropic action dependent on $\mathrm{G}$ proteins and IP3 synthesis.
The protective effect of AMPA/kainate receptor antagonists in different white matter injury paradigms was suggested to be secondary to sparing of glial elements, possibly leading to a reduction of diffusible messengers (eg, nitric oxide $[\mathrm{NO}]$ and free radicals) that may potentially damage axons (for review, see Matute and colleagues ${ }^{9}$ ). To investigate a potential role of $\mathrm{NO}$ in the AMPA- or ATPA-induced $\mathrm{Ca}^{2+}$ responses, we used the NO scavenger myoglobin. ${ }^{27} \mathrm{Se}-$ lective intracellular loading of axons with myoglobin, which will scavenge $\mathrm{NO}$ originating both from within and from outside the axon, significantly reduced axoplasmic $\mathrm{Ca}^{2+}$ increase induced by ATPA $(61 \pm 34 \%$; $\mathrm{n}=45 ; p=10^{-8}$ vs no myoglobin) but did not reduce the AMPA response (92 $\pm 36 \%$; $\mathrm{n}=29$; $p=$ 0.95 vs no myoglobin), suggesting that only the GluR5-mediated ATPA response depended (at least partially) on NO production (Fig 3). To demonstrate an intraaxonal action of NO in response to GluR5 activation, we repeated the ATPA experiment with bathapplied myoglobin, which failed to blunt the axonal $\mathrm{Ca}^{2+}$ response ( $\mathrm{F}_{\text {Ca.ax }}$ increase: $144 \pm 39 \% ; \mathrm{n}=24$; $p=0.99$ vs no bath-applied myoglobin). Together, the earlier results suggest a close functional relation between GluR5 kainate receptors and NO production in myelinated axons, likely synthesized by nNOS. Indeed, the partial reduction of the GluR5-mediated $\mathrm{Ca}^{2+}$ re-

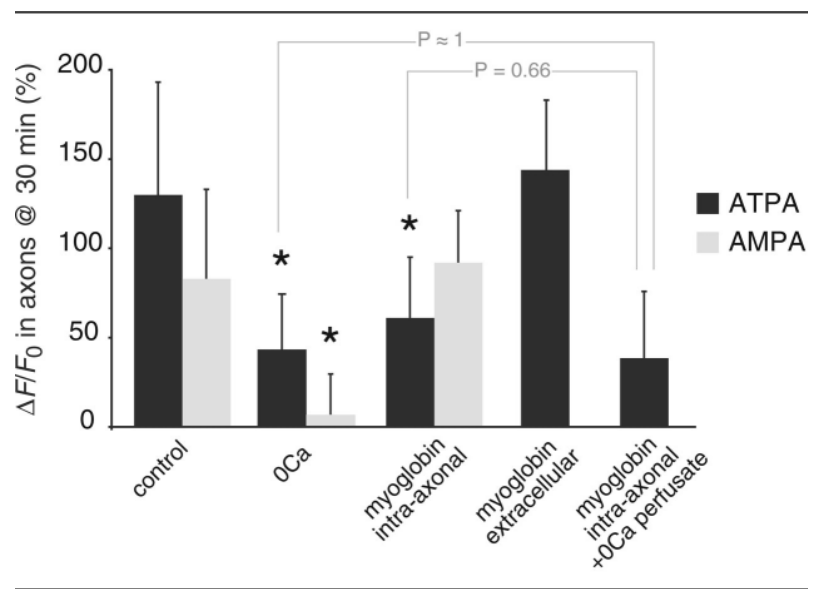

Fig 3. Glutamate receptor 5 (GluR5), but not $\alpha$-amino-3hydroxy-5-methyl-4-isoxazolepropionic acid (AMPA; grey bars), receptor-induced axonal $\mathrm{Ca}^{2+}$ responses partially depended on intraaxonal nitric oxide (NO). Intraaxonal loading of the NO scavenger myoglobin significantly reduced the $\mathrm{Ca}^{2+}$ response induced by (RS)-2-amino-3-(3-hydroxy-5-tert-butylisoxazol-4yl)propanoic acid (ATPA; black bars), but not by AMPA. Extracellular application of myoglobin did not reduce axonal $\mathrm{Ca}^{2+}$ increase induced by ATPA, suggesting an intraaxonal production of NO in response to GluR5 activation. Removal of bath $\mathrm{Ca}^{2+}$ or intraaxonal myoglobin was remarkably similar. In addition, combined removal of bath $\mathrm{Ca}^{2+}$ and intraaxonal myoglobin was not additive, suggesting a common mechanism. ${ }_{*}^{*} \leq 10^{-5}$ compared with respective agonist controls. 
sponse by removal of bath $\mathrm{Ca}^{2+}$ is remarkably similar to that seen with intraaxonal myoglobin (see Fig 3) $(p=0.93)$. Moreover, combined removal of bath $\mathrm{Ca}^{2+}$ and intraaxonal myoglobin is not additive $\left(\mathrm{F}_{\text {Ca.ax }}\right.$ increase: $38 \pm 36 \%, \mathrm{n}=33, p \approx 1$ vs ATPA+ zero$\mathrm{Ca}^{2+} /$ EGTA; $p=0.66$ vs ATPA+ intraaxonal myoglobin). nNOS is a $\mathrm{Ca}^{2+}$-activated enzyme ${ }^{28}$; therefore, it is quite plausible that the small quantity of $\mathrm{Ca}^{2+}$ admitted across the axolemma by GluR5 serves to promote $\mathrm{NO}$ synthesis, which, in turn, may amplify the "metabotropic" arm of the GluR5-dependent pathway, ultimately leading to $\mathrm{Ca}^{2+}$ release from IP3dependent stores. This $\mathrm{Ca}^{2+}$ release can further enhance nNOS function (eg, $\mathrm{Xu}$ and colleagues $^{29}$ ), thus providing $\mathrm{Ca}^{2+}$-dependent positive feedback in an environment (ie, the periaxonal space) where sources of $\mathrm{Ca}^{2+}$ are limited. Further evidence linking GluR5 with NO synthesis by nNOS is provided by immunochemical methods.

Immunohistochemical characterization of GluR5 and $\mathrm{nNOS}$ in dorsal columns showed frequent punctate staining at the surfaces of neurofilament-positive axon cylinders (Fig 4). Approximately 39\% of GluR5 clusters present at the axon surface were colocalized with nNOS (see Fig 4F); conversely, 58\% of nNOS clusters were colocalized with punctate GluR5 staining. This indicates that these signaling molecules may be distributed for other roles, such as nNOS association with the axonal GluR6 kainate receptor subtype. ${ }^{1}$ Moreover, immunoelectron microscopy confirmed that many GluR5-positive clusters were localized to the axolemma, rather than overlying myelin (see Fig 4G). In addition, immunoprecipitation of dorsal column lysate with a GluR5 antibody resulted in a strong band immunoreactive for nNOS (see Fig $4 \mathrm{H}$ ), indicating that these proteins are physically associated in this tissue. Taken together, these data are consistent with expression of GluR5 kainate receptors on the internodal axolemma and suggest that these receptors activate nNOS to generate intraaxonal NO. A similar punctate staining pattern was observed for GluR4 (see Fig 4A), indicating that AMPA receptors are also expressed on the axolemma under the internodal myelin sheath, further supported by the immunogold staining in Figure 4C.

\section{Discussion}

Glutamate-mediated toxicity of white matter has been described in several studies, many of which have implicated glutamate receptors ${ }^{2,4,14-16,18}$; glutathione depletion by glutamate-cystine exchange in oligodendrocytes, also plays a role in glutamate-dependent damage in cultured oligodendrocytes. ${ }^{30}$ These glia, which have been shown in vivo and in vitro to be particularly sensitive to excitotoxic insults, were considered the main cellular target of glutamate action, ${ }^{9}$ whereas astrocytes appear far more resistant to this neurotransmitter. ${ }^{30}$
Here, we show that, in addition to a glial effect of glutamate, GluR5-containing kainate receptors and GluR4-containing AMPA receptors are expressed on the internodal axolemma in central myelinated fibers and directly participate in mediating axonal $\mathrm{Ca}^{2+}$ increases in responses to agonist. These receptors are well poised to mediate deleterious $\mathrm{Ca}^{2+}$ deregulation in axons; indeed, white matter vulnerability to ischemia increases with age, ${ }^{31}$ and it is quite conceivable that these axonal receptors are directly responsible for promoting axonal degeneration in a variety of disease states.

The numerous colocalized and physically associated GluR5 receptors and nNOS clusters distributed along axon cylinders are similar to previously reported $\mathrm{Ca}^{2+}$ channel/ryanodine receptor clusters ${ }^{22}$ and GluR6/ nNOS "nanocomplexes." It appears, therefore, that the internodal axolemma exhibits an even richer collection of signaling molecules than was previously thought, now including GluR4, GluR5, and GluR6, the latter two physically and functionally associated with nNOS. The focal clustering of the above receptors and downstream effector molecules is curious, and suggests that the internodal axolemma is an inhomogeneous structure exhibiting highly specialized and spatially restricted functions. Indeed, in this study, GluR 4 AMPA receptors appear to admit small amounts of extracellular $\mathrm{Ca}^{2+}$, which is then amplified by CICR, dependent on ryanodine receptors. Unlike depolarizationinduced $\mathrm{Ca}^{2+}$ release, ${ }^{22}$ or GluR6-mediated $\mathrm{Ca}^{2+}$ increase, ${ }^{1}$ the AMPA receptor-dependent responses are independent of L-type $\mathrm{Ca}^{2+}$ channels, but instead appear dependent on $\mathrm{Ca}^{2+}$ ions admitted through the $\mathrm{Ca}^{2+}$-permeable receptor itself. CICR can be triggered by $\mathrm{Ca}^{2+}$-permeable channels other than voltage-gated channels; in dendritic spines, for instance, N-methylD-aspartate receptor-mediated $\mathrm{Ca}^{2+}$ influx triggers $\mathrm{Ca}^{2+}$ release from ryanodine-sensitive stores. ${ }^{32}$ The purpose of CICR in axons is unknown but may parallel other cells where internal $\mathrm{Ca}^{2+}$ provides the majority of a biochemical signal. In cardiac myocytes, for instance, $80 \%$ of the $\mathrm{Ca}^{2+}$ responsible for contraction originates from the sarcoplasmic reticulum, mobilized via CICR. ${ }^{33}$ It is likely that myelination heavily restricts the availability of extracellular $\mathrm{Ca}^{2+}$ for signaling in the internodal periaxonal space; therefore, axons may have adopted a strategy for amplifying these $\mathrm{Ca}^{2+}$ signals by instead relying on internal sources, with a small influx of this ion across the axolemma being a sufficient trigger. In contrast with the AMPA-mediated responses, the GluR5-mediated $\mathrm{Ca}^{2+}$ increase occurs by both canonical (ie, ionotropic) and noncanonical (metabotropic) signaling, whereby a small inflow of $\mathrm{Ca}^{2+}$ is amplified through a G-protein, phospholipase C-dependent cascade, ultimately leading to $\mathrm{Ca}^{2+}$ release from IP3-dependent $\mathrm{Ca}^{2+}$ stores. In contrast with the AMPA-dependent effect, this GluR5-mediated 

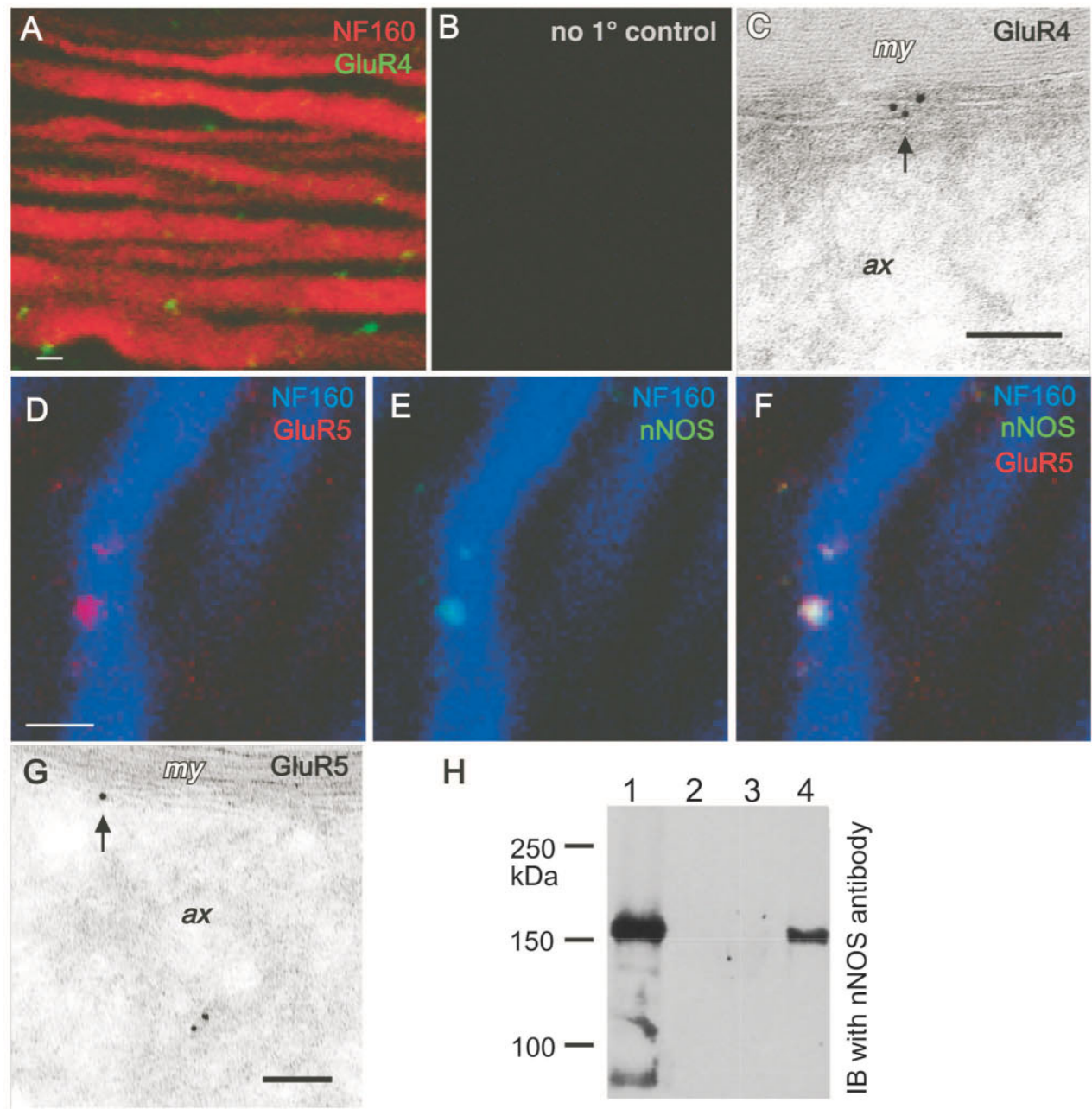

H

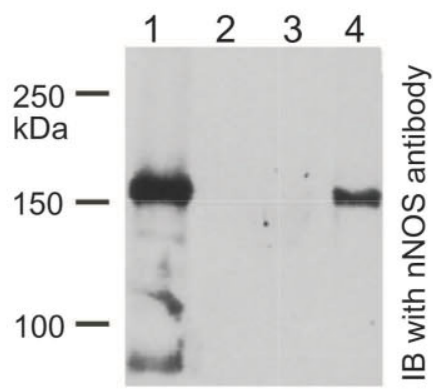

Fig 4. Glutamate receptor 4 (GluR4)-containing $\alpha$-amino-3-hydroxy-5-methyl-4-isoxazolepropionic acid (AMPA) and GluR5containing kainate receptors are present on the internodal axolemma. (A) Immunolabeled dorsal column axons showing punctate regions of GluR4 clusters at the surface of neurofilament-stained axon cylinders. (B) Representative control section with primary antibodies omitted showed little nonspecific labeling. (C) Immunogold labeling using GluR4 primary antibody showed signal at the axolemma in a myelinated internode (arrow). (D-F) Triple-immunolabeled dorsal column axons showed occasional punctate regions of colocalized GluR5 and neuronal nitric oxide synthase ( $n N O S$ ) clusters at the surface of neurofilament-stained axon cylinders. (G) Immunogold labeling using GluR5 primary antibody confirmed signal at the axolemma in a myelinated internode. Occasional intraaxonal signal was also seen. (H) Immunoprecipitation with GluR5 antibody showed a specific interaction between this kainate receptor and nNOS, in agreement with their functional link (see Fig 3). Lane $1=$ whole dorsal column lysate probed with nNOS antibody showed an expected main band at approximately 160kDa. Lane $2=$ beads + dorsal column lysate (no GluR5 antibody) showed no nonspecific nNOS signal. Lane $3=$ beads + GluR5 precipitating antibody (no dorsal column lysate) showed no nNOS signal. Lane $4=$ immunoprecipitation with GluR5 antibody and immunoblot with nNOS showed a single specific nNOS-reactive band at the expected molecular weight. ax = axon; my = myelin; NF160 = neurofilament 160. IB = immunoblot. Scale bars panels $A, D: 2 \mu \mathrm{m}$. C, G: $100 \mathrm{~nm}$.

mechanism is upregulated by $\mathrm{NO}$, likely synthesized by nNOS within the axon; the mechanism by which NO stimulates IP3-dependent $\mathrm{Ca}^{2+}$ release is unknown but may involve direct or indirect (via activation of soluble guanylate cyclase) activation of IP3 receptor activity ${ }^{34}$ (see Fig 6 in the accompanying article ${ }^{1}$ ).

Axonal pathology from many different insults such as ischemia, trauma, and immune attack shares remarkable similarities, with focal swelling and often irrevers- ible transection of the fiber. ${ }^{35}$ Although the pathophysiological mechanisms of axonal swelling and transection are unknown, it is interesting to speculate that the highly localized clusters of signaling molecules on the internodal axolemma, each leading to localized $\mathrm{Ca}^{2+}$ release, may induce focal destruction of axonal cytoarchitecture, in turn possibly leading to the localized axonal pathology observed in many disorders. If so, this raises interesting therapeutic possibilities to re- 
duce axonal damage in many disorders such neurotrauma, multiple sclerosis, and stroke. Our observations further underscore the parallels between neurons and myelinated axons with respect to the "source specificity" of $\mathrm{Ca}^{2+}$ loading, whereby the locus of $\mathrm{Ca}^{2+}$ entry (via channels)/release (from intracellular $\mathrm{Ca}^{2+}$ stores) may be more important than the total cellular $\mathrm{Ca}^{2+}$ load. ${ }^{36,37}$

This work was supported by the NIH (National Institute of Neurological Disorders and Stroke, P.K.S., B.D.T.), Canadian Institutes of Health Research (P.K.S. \#FRN 37858, G.W.Z. \#MOP 14172), Heart and Stroke Foundation of Ontario Center for Stroke Recovery, Heart and Stroke Foundation of Ontario Career Investigator Award (P.K.S), Alberta Heritage Foundation for Medical Research Scientist Award (P.K.S., G.W.Z.), and private donors (P.K.S). GWZ and PKS are Canada Research Chairs (Tier 1).

\section{References}

1. Ouardouz M, Coderre E, Basak A, et al. Glutamate receptors on myelinated spinal cord axons: I. GluR6 kainate receptors. Ann Neurol 2009;65:151-159.

2. Agrawal SK, Fehlings MG. Role of NMDA and non-NMDA ionotropic glutamate receptors in traumatic spinal cord axonal injury. J Neurosci 1997;17:1055-1063.

3. Gallo V, Ghiani CA. Glutamate receptors in glia: new cells, new inputs and new functions. Trends Pharmacol Sci 2000;21: $252-258$.

4. Li S, Stys PK. Mechanisms of ionotropic glutamate receptormediated excitotoxicity in isolated spinal cord white matter. J Neurosci 2000;20:1190-1198.

5. Park E, Liu Y, Fehlings MG. Changes in glial cell white matter AMPA receptor expression after spinal cord injury and relationship to apoptotic cell death. Exp Neurol 2003;182:35-48.

6. Steinhauser C, Gallo V. News on glutamate receptors in glial cells. Trends Neurosci 1996;19:339-345.

7. Verkhratsky A, Steinhauser C. Ion channels in glial cells. Brain Res Brain Res Rev 2000;32:380-412.

8. Yoshioka A, Bacskai B, Pleasure D. Pathophysiology of oligodendroglial excitotoxicity. J Neurosci Res 1996;46:427-437.

9. Matute C, Alberdi E, Domercq M, et al. The link between excitotoxic oligodendroglial death and demyelinating diseases. Trends Neurosci 2001;24:224-230.

10. Matute C, Sanchez-Gomez MV, Martinez-Millan L, et al. Glutamate receptor-mediated toxicity in optic nerve oligodendrocytes. Proc Natl Acad Sci U S A 1997;94:8830-8835.

11. McDonald JW, Althomsons SP, Hyrc KL, et al. Oligodendrocytes from forebrain are highly vulnerable to AMPA/kainate receptor-mediated excitotoxicity. Nat Med 1998;4:291-297.

12. Tekkok SB, Goldberg MP. AMPA/kainate receptor activation mediates hypoxic oligodendrocyte death and axonal injury in cerebral white matter. J Neurosci 2001;21:4237-4248.

13. McCracken E, Fowler JH, Dewar D, et al. Grey matter and white matter ischemic damage is reduced by the competitive AMPA receptor antagonist, SPD 502. J Cereb Blood Flow Metab 2002;22:1090-1097.

14. Pitt D, Werner P, Raine CS. Glutamate excitotoxicity in a model of multiple sclerosis. Nat Med 2000;6:67-70.

15. Rosenberg LJ, Teng YD, Wrathall JR. 2,3-dihydroxy-6-nitro-7sulfamoyl-benzo $(f)$ quinoxaline reduces glial loss and acute white matter pathology after experimental spinal cord contusion. J Neurosci 1999;19:464-475.
16. Smith T, Groom A, Zhu B et al. Autoimmune encephalomyelitis ameliorated by AMPA antagonists. Nat Med 2000;6: 62-66.

17. Wrathall JR, Choiniere D, Teng YD. Dose-dependent reduction of tissue loss and functional impairment after spinal cord trauma with the AMPA/kainate antagonist NBQX. J Neurosci 1994;14:6598-6607.

18. Wrathall JR, Teng YD, Marriott R. Delayed antagonism of AMPA/kainate receptors reduces long-term functional deficits resulting from spinal cord trauma. Exp Neurol 1997;145: 565-573.

19. Micu I, Coderre E, Jiang Q, et al. NMDA receptors mediate $\mathrm{Ca}$ accumulation in central nervous system myelin during chemical ischemia. Nature 2006;439:988-992.

20. Clarke VR, Ballyk BA, Hoo KH, et al. A hippocampal GluR5 kainate receptor regulating inhibitory synaptic transmission. Nature 1997;389:599-603.

21. Mayer ML, Ghosal A, Dolman NP, et al. Crystal structures of the kainate receptor GluR5 ligand binding core dimer with novel GluR5-selective antagonists. J Neurosci 2006;26: 2852-2861.

22. Ouardouz M, Nikolaeva M, Coderre E, et al. Depolarizationinduced $\mathrm{Ca} 2+$ release in ischemic spinal cord white matter involves L-type $\mathrm{Ca} 2+$ channel activation of ryanodine receptors. Neuron 2003;40:53-63.

23. Lerma J. Kainate receptor physiology. Curr Opin Pharmacol 2006;6:89-97.

24. Rozas JL, Paternain AV, Lerma J. Noncanonical signaling by ionotropic kainate receptors. Neuron 2003;39:543-553.

25. Berridge MJ. Cardiac calcium signalling. Biochem Soc Trans 2003;31:930-933.

26. Foskett JK, White $\mathrm{C}$, Cheung $\mathrm{KH}$, et al. Inositol trisphosphate receptor Ca2+ release channels. Physiol Rev 2007;87:593-658.

27. Flogel U, Merx MW, Godecke A, et al. Myoglobin: a scavenger of bioactive NO. Proc Natl Acad Sci U S A 2001;98:735-740.

28. Moncada S, Palmer RM, Higgs EA. Nitric oxide: physiology, pathophysiology, and pharmacology. Pharmacol Rev 1991;43: $109-142$.

29. Xu X, Star RA, Tortorici G, et al. Depletion of intracellular $\mathrm{Ca} 2+$ stores activates nitric-oxide synthase to generate cGMP and regulate Ca2+ influx. J Biol Chem 1994;269: 12645-12653.

30. Oka A, Belliveau MJ, Rosenberg PA, et al. Vulnerability of oligodendroglia to glutamate: pharmacology, mechanisms, and prevention. J Neurosci 1993;13:1441-1453.

31. Baltan S, Besancon EF, Mbow B, et al. White matter vulnerability to ischemic injury increases with age because of enhanced excitotoxicity. J Neurosci 2008;28:1479-1489.

32. Emptage N, Bliss TV, Fine A. Single synaptic events evoke NMDA receptor-mediated release of calcium from internal stores in hippocampal dendritic spines. Neuron 1999;22: 115-124.

33. Philipson KD, Nicoll DA. Sodium-calcium exchange: a molecular perspective. Annu Rev Physiol 2000;62:111-133.

34. Vicente S, Figueroa S, Perez-Rodriguez R, et al. Nitric oxide donors induce calcium-mobilisation from internal stores but do not stimulate catecholamine secretion by bovine chromaffin cells in resting conditions. Cell Calcium 2005;37:163-172.

35. Trapp BD, Peterson J, Ransohoff RM, et al. Axonal transection in the lesions of multiple sclerosis. N Engl J Med 1998;338: $278-285$.

36. Sattler R, Charlton MP, Hafner M, et al. Distinct influx pathways, not calcium load, determine neuronal vulnerability to calcium neurotoxicity. J Neurochem 1998;71:2349-2364.

37. Sattler R, Tymianski M. Molecular mechanisms of calciumdependent excitotoxicity. J Mol Med 2000;78:3-13. 